\title{
MEDICAL REHABILITATION AND INFECTIOUS DISEASES IN CHILDREN
}

Melnikova EV ${ }^{1,2} \otimes$, Khasanova NM ${ }^{1,3}$, Chuprova SN ${ }^{1,4}$, Uskov AN ${ }^{1}$, Skripchenko NV ${ }^{1,5}$, Samoylova IG ${ }^{1}$, Lepikhina TG ${ }^{1}$, Ivanova GY ${ }^{6,7}$

1 Pediatric Research and Clinical Center for Infectious Diseases of FMBA, Saint Petersburg, Russia

2 Private University «Saint Petersburg Medico-Social Institute», Saint Petersburg, Russia

${ }^{3}$ Northern State Medical University, Arkhangelsk, Russia

${ }^{4}$ Mechnikov North-Western State Medical University, Saint Petersburg, Russia

${ }^{5}$ Saint Petersburg State Pediatric Medical University, Saint Petersburg, Russia

${ }^{6}$ Pirogov Russian National Research Medical University, Moscow, Russia

${ }^{7}$ Federal Center for Brain Research and Neurotechnologies of FMBA, Moscow, Russia

Today, medical rehabilitation is undergoing significant transformation. The new system built around the biopsychosocial model includes assessment of physical constraints and rehabilitation diagnosis, determination of rehabilitation potential, formulation of goals and objectives of individual interventions, development of rehabilitation plans, and progress evaluation. All of these rehabilitation components can be implemented using a personalized, problem-oriented, multidisciplinary approach, which is now being actively introduced into clinical practice. The current pandemic of the novel coronavirus infection has demonstrated that medical rehabilitation is crucial for convalescents. However, its principles and techniques have not been fully elaborated yet. This review describes the current state of medical rehabilitation of children with or after infectious diseases and identifies its avenues and prospects.

Keywords: children, rehabilitation, infectious diseases, ICF, telemedicine, biopsychosocial model, personalized approach, COVID-19

$\triangle$ Correspondence should be addressed: Elena V. Melnikova

Professora Popova, 9, Saint Petersburg, 197022, Russia; melnikovae2002@mail.ru

Received: 03.12.2021 Accepted: 16.12.2021 Published online: 21.12.2021

DOI: $10.47183 /$ mes.2021.043

\section{МЕДИЦИНСКАЯ РЕАБИЛИТАЦИЯ И ИНФЕКЦИОННЫЕ БОЛЕЗНИ У ДЕТЕЙ}

Е. В. Мельникова ${ }^{1,2}$, Н. М. Хасанова ${ }^{1,3}$, С. Н. Чупрова ${ }^{1,4}$, А. Н. Усков ${ }^{1}$, Н. В. Скрипченко ${ }^{1,5}$, И. Г. Самойлова

1 Детский научно-клинический центр инфекционных болезней Федерального медико-биологического агентства, Санкт-Петербург, Россия

2 Санкт-Петербургский медико-социальный институт, Санкт-Петербург, Россия

${ }^{3}$ Северный государственный медицинский университет, Архангельск, Россия

${ }^{4}$ Северо-Западный государственный медицинский университет имени И. И. Мечникова, Санкт-Петербург, Россия

${ }^{5}$ Санкт-Петербургский государственный педиатрический медицинский университет, Санкт-Петербург, Россия

${ }^{6}$ Российский национальный исследовательский университет имени Н. И. Пирогова, Москва, Россия

7 Федеральный центр мозга и нейротехнологий Федерального медико-биологического агентства, Москва, Россия

Медицинская реабилитация в наши дни претерпевает существенные изменения. Эта новая, выстраиваемая на основе биопсихосоциальной модели, система, включает в себя оценку ограничений жизнедеятельности, определение реабилитационного диагноза и реабилитационного потенциала, формирование цели и отдельных задач реабилитационных вмешательств, построение и осуществление плана реабилитационных интервенций с последующей оценкой достигнутых результатов. Все эти действия возможны в условиях реализации персонисицированного, проблемно-ориентированного и мультидисциплинарного подходов, которые сейчас активно внедряются в клиническую практику. Пандемия новой коронавирусной инфекции определила жизненную необходимость медицинской реабилитации реконвалесцентов инфекционных болезней, принципы и технологии которой не отработаны до настоящего времени. В обзоре представлено состояние современной медицинской реабилитации в детской инфектологии, специфика медицинской реабилитации у детей в условиях инфекционного процесса и после его завершения. Определены основные направления медицинской реабилитации детей с инфекционными болезнями и перспективы ее развития.

Ключевые слова: дети, реабилитация, инфекционные заболевания, МКФ, телемедицина, биопсихосоциальная модель, персонифицированный подход, COVID-19

$\triangle$ Для корреспонденции: Елена Валентиновна Мельникова ул. профессора Попова, д. 9, г. Санкт-Петербург, 197022; melnikovae2002@mail.ru

Статья получена: 03.12.2021 Статья принята к печати: 16.12.2021 Опубликована онлайн: 21.12.2021

DOI: $10.47183 /$ mes.2021.043

The conventional approaches to medical rehabilitation adopted in Russia are undergoing significant transformation toward the biopsychosocial model of disease that public healthcare is yet to fully incorporate. Unlike the classical biomedical model, the biopsychosocial model is not constrained by the nosological approach and sees disease as a complex of biological, psychological and social processes [1]. Apart from focusing on the biological factors implicated in disease, biopsychosocial rehabilitation actively exploits psychological and social approaches to recovery and thus can exert broader effects on sanogenesis.

In the past decade, this new model of medical rehabilitation has been actively implemented in Russia. New rehabilitation specialties have emerged, including physical medicine and rehabilitation doctors and rehabilitation nurses indispensable to the multidisciplinary rehabilitation team. Professional standards have been elaborated for healthcare workers engaged in ergotherapy (ergotherapists, ergospecialists), physical therapy (physical therapists, kinesiotherapists), speech therapy, and medical psychology [2, 3].

According to the now effective legislation on medical rehabilitation, the latter must be multidisciplinary in nature and utilize the International Classification of Functioning, Disability and Health (ICF) [4].

Being a representation of the biopsychosocial disease model, ICF provides a framework for rehabilitation: based on 
the ICF-coded diagnosis, the ultimate goal of rehabilitation and its smaller objectives are identified, the rehabilitation plan is designed (considering the rehabilitation potential) and rehabilitation outcomes are evaluated [5].

Developmental issues are a serious ramification of childhood diseases; therefore, a series of consecutive rehabilitation courses may be needed for children with a past history of disease, each course being a continuation of the previous one. Children may develop concurrent debilitating conditions that together produce a devastating effect. Establishing a good rapport with children and their parents is critical for successful pediatric rehabilitation. Immediate family (ICF code e310) is an environmental factor that has a tremendous impact on the child's health. Many problems experienced by the child may be linked to the individual attitudes perpetuated in the family (ICF code e410). Another important contributor is physical environment (Products and Technology, ICF code e1): skills and activities are learnt through the interaction with the environment, which is ideally fosters development and is a powerful rehabilitation tool. Restricting children in their basic activities, including mobility, may preclude other activities and cause secondary damage to cognitive development.

The medical rehabilitation of today is very much different from what it was in the past. Its concept raises the need for rethinking and refining rehabilitation strategies and techniques. Approaches to rehabilitation are changing in every medical field, including the domain of pediatric infectious diseases.

Pediatric infectious diseases are very common, making up $90 \%$ of childhood diseases $[6,7]$. The most prevalent are acute respiratory infections: their incidence among children is 2.5-2.9 times higher than among adults [8]. The impact of pediatric infections on child health and development is difficult to underestimate, considering current trends in their incidence and the spread of the novel coronavirus infection, which has convincingly shown that infections are still one of the primary threats to mankind. Today, old infections are resurfacing and novel infections are emerging. Antimicrobial resistance, human microbiome transformation and herd immunity fluctuations remain a serious challenge. The economic burden of infections is growing $[9,10]$.

This review covers Pubmed, e-library and Cochrane library publications of the past decade focusing on the medical rehabilitation of children with a history of infectious diseases.

\section{Neuroinfections}

Neuroinfections are among the leading contributors to pediatric morbidity from infectious diseases. Half of pediatric patients with neuroinfections develop disabilities with persistent organic symptoms in the residual period [11, 12]. Poor outcomes may be associated with the child's age, the corresponding stage of brain development and vulnerability of some CNS structures. Pre-existing pathology of the nervous system can aggravate the damage [11].

High demand for rehabilitation is associated with severe sequelae of neuroinfectious diseases; some authors emphasize the importance of starting rehabilitation in the acute stage of the disease because the early commencement of rehabilitation therapy may determine rehabilitation potential and prevent complications or disability [13].

According to publications investigating the outcomes of neuroinfections, mechanisms underlying neurological deficit and cognitive disorders remain understudied, meta-analyses are scarce and there are certain difficulties in formulating conclusions [14-17]. The long-term neurological consequences of neuroinfections that reduce the quality of the patient's life are observed in 25-63\% of cases [17, 18]. While studying the outcomes of neuroinfections, many authors focus on immunization, premorbidities, length of hospital stay, timeframe and choice of antibacterial or glucocorticoid therapy, nutritional status, and dehydration [14, 19-22]. Unfortunately, the effects of rehabilitation on the outcomes of neuroinfection are barely discussed.

Children with a past history of neuroinfection experience a variety of health problems differing in form and severity. Those include cognitive impairment, autonomic disorders, attention deficit/hyperactivity disorder, central or peripheral paresis, coordination disorders and speech impairment, epilepsy, etc. [6]. The meta-analysis of 868 meningococcal meningitis cases [17] revealed the presence of residual symptoms in $18 \%$ of the patients manifesting as hearing loss (5.4\%), skin scarring $(5.4 \%)$, renal dysfunction $(2.6 \%)$ or seizures $(2.5 \%)$. Cerebrasthenia was observed in $40-85 \%$ of convalescent children with aseptic meningitis, whereas reduced working memory was reported in $24 \%$ of cases; these conditions persisted for up to 6 months in 20-40\% of the patients [23]. Among other neuroinfection sequelae reported in the literature are increased intracranial pressure (13\%), diencephalic (16\%) and focal (10\%) manifestations. Neurasthenia (35\%), increased intracranial pressure (19\%) and symptomatic epilepsy (3\%) can last for over a year following the infection [6]. Significant functional decline is observed after infectious encephalitis $[24,25]$. Almost $80 \%$ of patients with encephalitis suffer from neuropsychological impairment. There are reports of attention and behavioral deficits and emotional impairment continuing for 3 years after the acute phase of the disease [26, 25].

According to an American study, 37 of 55 children infected with tick-borne encephalitis in 2004-2008 had cognitive deficit, headaches, fatigue and irritability 2-5 years after the infection. Parent and teacher surveys revealed that over one-third of the affected children had behavioral problems, motivational deficiency and reduced working memory [27]. Similar findings were reported by Swedish, Chinese and Russian researchers. Attention deficit/hyperactivity disorder was diagnosed in 50\% of children with a past history of tick-borne encephalitis in both early and late postinfectious periods [27-29]. Another concern is postinfectious epilepsy. Over half of children infected with encephalitis develop seizures in the acute stage of the disease [30]. Besides, patients with postinfectious epilepsy are at increased risk for depression and anxiety [31].

According to the nationwide population-based cohort study that relied on the data from Danish registries collected in 19802008, adults with a past history of childhood neuroinfection are less educated, less financially secure, less involved socially and are dependent on disability payments [32].

Canadian researchers attempted to conduct a metaanalysis of 20 studies on rehabilitation after infectious encephalitis extracted from 12,737 sources. Nine of the included studies investigated the effects of cognitive therapy, 5 looked at behavioral therapy, 2 focused on physical therapy and 4 on complex rehabilitation involving 2 or more types of therapy. Unfortunately, due to small sample size (no more than 25 patients in each case) and clinical and methodological heterogeneity, the meta-analysis failed [33, 34].

Another study demonstrated a reduced quality of life 6 months after encephalitis for both children and adults [35, 36].

The following conditions are reported in children with a medical history of herpes simplex encephalitis: diverse neurological symptoms (tetraparesis, hydrocephalus, symptomatic epilepsy, developmental delay) in the first year of 
Table. Domains of functional and structural damage in convalescent children after infectious disease (from [64], printed by permission of the authors)

\begin{tabular}{|c|c|c|}
\hline \multirow{2}{*}{ Clinical examples (diagnoses) } & \multicolumn{2}{|r|}{ Domains and functional/structural damage categories } \\
\hline & Code & Domains and categories \\
\hline Prolonged neonatal jaundice & b 598.1 & Mild disorders of the digestive, metabolic and endocrine systems, other specified \\
\hline Hepatitis B & $\begin{array}{l}\text { b } 515.1 \\
\text { b } 525.1 \\
\text { b } 535.1 \\
\text { s } 560.17\end{array}$ & $\begin{array}{l}\text { Mild disorders of digestive functions } \\
\text { Mild disorders of defecation functions } \\
\text { Mild disorders of sensations associated with the digestive system } \\
\text { Mild changes to liver structure }\end{array}$ \\
\hline $\begin{array}{l}\text { Chronic CMV hepatitis resulting } \\
\text { in fibrosis }\end{array}$ & $\begin{array}{l}\text { b } 515.2 \\
\text { b } 525.2 \\
\text { b } 535.2 \\
\text { s } 560.27\end{array}$ & $\begin{array}{l}\text { Moderate disorders of digestive functions } \\
\text { Moderate disorders of defecation functions } \\
\text { Moderate disorders of sensations associated with the digestive system } \\
\text { Moderate changes to liver structure }\end{array}$ \\
\hline $\begin{array}{l}\text { Highly active autoimmune } \\
\text { hepatitis, developing cirrhosis }\end{array}$ & $\begin{array}{l}\text { b } 515.3 \\
\text { b } 520.3 \\
\text { b } 525.2 \\
\text { b } 530.3 \\
\text { b } 535.3 \\
\text { b } 550.2 \\
\text { b } 430.3 \\
\text { b } 435.3 \\
\text { s } 560.37\end{array}$ & $\begin{array}{l}\text { Severe disorders of digestive functions } \\
\text { Severe disorders of assimilation functions } \\
\text { Severe disorders of defecation functions } \\
\text { Severe disorders of weight maintenance functions } \\
\text { Severe disorders of sensations associated with the digestive system } \\
\text { Moderate disorders of thermoregulatory functions } \\
\text { Severe disorders of hematological system functions } \\
\text { Severe disorders of immunological system functions } \\
\text { Severe changes to liver structure }\end{array}$ \\
\hline $\begin{array}{l}\text { TTV hepatitis in the presence } \\
\text { of hepatic steatosis, metabolic } \\
\text { syndrome, asthma }\end{array}$ & $\begin{array}{l}\text { b } 515.3 \\
\text { b } 520.3 \\
\text { b } 540.3 \\
\text { b } 545.2 \\
\text { b } 555.2 \\
\text { b } 440.1 \\
\text { b } 455.2 \\
\text { b } 460.2 \\
\text { s } 560.37\end{array}$ & $\begin{array}{l}\text { Severe disorders of digestive functions } \\
\text { Severe disorders of assimilation functions } \\
\text { Severe disorders of general metabolic functions } \\
\text { Moderate disorders of water, mineral and electrolyte balance functions } \\
\text { Moderate disorders of endocrine gland functions } \\
\text { Mild disorders of respiration functions } \\
\text { Moderate disorders of exercise tolerance functions } \\
\text { Moderate disorders of sensations associated with cardiovascular and respiratory functions } \\
\text { Severe changes to liver structure }\end{array}$ \\
\hline Salmonella-induced dysbiosis & $\begin{array}{l}\text { b } 515.2 \\
\text { b } 520.2 \\
\text { b } 525.2 \\
\text { b } 530.2 \\
\text { b } 535.2 \\
\text { b } 540.2\end{array}$ & $\begin{array}{l}\text { Moderate disorders of digestive functions } \\
\text { Moderate disorders of assimilation functions } \\
\text { Moderate disorders of defecation functions } \\
\text { Moderate disorders of weight maintenance functions } \\
\text { Moderate disorders of sensations associated with the digestive system } \\
\text { Moderate disorders of general metabolic functions }\end{array}$ \\
\hline Enteroviral meningitis & $\begin{array}{l}\text { b } 126.1 \\
\text { b } 130.1 \\
\text { b } 134.1 \\
\text { b } 147.1\end{array}$ & $\begin{array}{l}\text { Mild disorders of temperament and personality functions } \\
\text { Mild disorders of energy and drive functions } \\
\text { Mild disorders of sleep functions } \\
\text { Mild disorders of psychomotor functions }\end{array}$ \\
\hline Haemophilus meningitis & $\begin{array}{l}\text { b } 126.3 \\
\text { b } 130.3 \\
\text { b } 134.3 \\
\text { b } 147.3 \\
\text { s } 130.27\end{array}$ & $\begin{array}{l}\text { Severe disorders of temperament and personality functions } \\
\text { Severe disorders of energy and drive functions } \\
\text { Severe disorders of sleep functions } \\
\text { Severe disorders of psychomotor functions } \\
\text { Moderate changes to the structure of meninges }\end{array}$ \\
\hline Obstructive bronchitis & $\begin{array}{l}\text { b } 440.1 \\
\text { b } 435.1\end{array}$ & $\begin{array}{l}\text { Mild disorders of respiration functions } \\
\text { Mild disorders of immunological system functions }\end{array}$ \\
\hline $\begin{array}{l}\text { Chronic bronchiolitis, diffuse } \\
\text { bronchiectasis, stage } 1 \text { chronic } \\
\text { respiratory failure }\end{array}$ & $\begin{array}{l}\text { b } 410.2 \\
\text { b } 440.2 \\
\text { b } 435.2 \\
\text { b } 455.2 \\
\text { b } 460.2 \\
\text { s } 410.27 \\
\text { s } 430.273\end{array}$ & $\begin{array}{l}\text { Moderate disorders of heart functions } \\
\text { Moderate disorders of respiration functions } \\
\text { Moderate disorders of immunological system functions } \\
\text { Moderate disorders of exercise tolerance functions } \\
\text { Moderate disorders of sensations associated with cardiovascular and respiratory functions } \\
\text { Moderate changes to the structure of cardiovascular system. } \\
\text { Moderate bilateral changes to the structure of respiratory system }\end{array}$ \\
\hline
\end{tabular}

life; motor skills disorder and a speech and language delay in children aged 1-3 years; ataxia, neurosis, neurosis-like states in preschoolers; emotional, volition and hypothalamus disorders, and intellectual disability in school children [6].

Focal demyelination caused by infection can result in residual neurologic deficit in $30 \%$ of children or have a progressive course leading to severe polysyndromic neurologic deficit in $20 \%$ of cases. Spinal cord and peripheral nervous system infections often manifest as myelopathy, myelopolyneuropathy, polyneuropathy, facial neuropathy, and polyradiculopathy [6].

Rehabilitation after neuroinfection includes early mobilization, physical exercise, massage, speech therapy, psychotherapy, body positioning, prophylaxis of pressure ulcers, contractures, pneumonia, and thrombotic complications. Motor rehabilitation should be step-wise and include training of movement components, proprioception enhancement, simple associated movements, joints, and motor skills. Children with peripheral paresis associated with myelitis or poliomyelitis should undergo therapy with electrical stimulation, paraffin or ozokerite applications, general fitness physical and respiratory exercise, special exercises for the affected limb, and hydrokinesiotherapy. To relieve pain, alleviate autonomic and trophic disturbances and regain motor function, a variety of interventions are recommended, including two or four-cell tub baths, diadynamic, sinusoidal modulated and interferential currents, ultrasound therapy and phonophoresis, therapy with alternating magnetic fields, ozokerite applications, and a combination of magnet and laser therapy. Other options include kinesiotherapy, robotic therapy for motor function recovery, standing and walking frames, dynamic proprioceptive correction, speech therapy, and biolfeedback therapy [6]. 
Complex rehabilitation and follow-up care are crucial for achieving complete recovery, especially when it comes to infants, whose immunity is underdeveloped and who are at risk for serious complications [13].

\section{Acute gastrointestinal infections}

Acute gastrointestinal infections are leading in incidence, both in Russa and worldwide [37, 38]. In 20-30\% of cases, acute gastrointestinal infections provoke functional gastrointestinal disorders [13]. It is known that acute intestinal infections cause dysbiosis and allergies, change the reactivity of the immune system, triggering autoimmune disorders, promote gastrointestinal pathology, have an adverse effect on the physical and mental development of the child [39]. In up to $30 \%$ of cases, children develop irritable bowel syndrome following acute intestinal infection. There is evidence that $25 \%$ of children with acute infectious diarrhea are at high risk of gallbladder, pancreas and bowel dysfunction 6 months after the infection [39]. There are reports of exacerbations of atopic dermatitis and developmental delay in children recovering from intestinal infections, suggesting that rehabilitation should start as early as the subacute stage of infection [13].

The primary objectives of rehabilitation at each of its stages are as follows: treatment of intestinal dysbiosis using galvanic therapy of the abdomen with topically applied microelements or microwave diathermy [40-42]; correction of functional and morphologic changes of intestinal mucosa (ultrahigh-frequency therapy, low-energy laser irradiation [43]), restoration of colon motility and normal evacuation (amplipulse therapy, interferential therapy, diadynamic therapy, localized cryotherapy, massage [40]); management of asthenia and autonomic disorders (magnet therapy, resonance frequency therapy [44]); hydrotherapy [40].

There is a paucity of studies focusing on the rehabilitation of pediatric patients with postinfectious cardiovascular disorders although their incidence is quite high [45]. Cardiac pathology associated with infection poses a high risk of complications, raising the need for timely diagnosis and adequate rehabilitation [46, 47].

\section{Novel coronavirus disease COVID-19}

This infection typically has respiratory and gastrointestinal presentations in children and adolescents [48-50]. Respiratory viral coinfection is diagnosed in $11-46 \%$ of patients with COVID-19 [51]. Severe COVID-19 is often observed in very young children or those who have preexisting cardiovascular disorders, chronic pulmonary conditions, compromised immunity, etc. [51-54].

Rehabilitation is needed for children with COVID-19 who develop lung damage [55, 56], cardiovascular complications [49], neurologic [57] and gastrointestinal [58, 59] disorders. The broad spectrum of neurologic sequelae of COVID-19 comprises anosmia, ageusia/dysgeusia, acute Guillain-Barrsyndrome, cerebral and spinal damage [57]. Follow-up care and rehabilitation are required for children with postinfectious asthenia persisting for 1-2 months in 30\% of patients. Clinically, it is manifested as increased fatiguability, malaise, mental and physical exhaustion [60, 61]. Regardless of the underlying mechanisms, forms and severity, damage to the nervous system that requires further rehabilitation manifests as asthenia, autonomic dysfunction, central or peripheral paresis, coordination impairment, seizures, and speech impairment.

Recent research has demonstrated that children with a past history of COVID-19 need rehabilitation regardless of the severity of disease (even when the disease is asymptomatic or mild). This is associated with the risk of functional impairment of respiratory and other systems. Rehabilitation includes physiotherapy, balneotherapy (pelotherapy), physical exercise, reflexotherapy, manual therapy, psychotherapy, etc. [62]. The principles of medical rehabilitation for children with COVID-19 are the same as for adults and account for small age and exercise tolerance [63].

Similar to other types of pediatric rehabilitation, medical rehabilitation of children with COVID-19 follows certain guidelines. Rehabilitation of children with COVID-19 is aimed at training and recovery of compensatory capacity of the bronchopulmonary and cardiovascular systems.

Rehabilitation for bronchopulmonary pathology associated with COVID-19 should include respiratory and psychological rehabilitation, nutritional support, and physical methods for managing bronchial obstruction syndrome (inhalation therapy, halotherapy) [50]. Respiratory muscle function can be supported through transcutaneous electrical stimulation of the diaphragm, mucostasis inhibition, huffing, and autogenic drainage. Rehabilitation techniques used in pediatric patients with COVID-19-associated neurological disorders depend on the child's age, the leading pathological syndrome, severity of respiratory disorders and can include muscle relaxation, motor skills training required for self-care, electrical muscle stimulation, motor correction, and therapy for neurasthenia. To restore bowel motility in children with COVID-19-associated intestinal disorders, amplipulse therapy, interferential therapy, localized cryotherapy, diadynamic therapy, massage, pine baths, and microwave diathermy (for children over 2 years of age) are recommended.

Is pediatric medical rehabilitation for infectious diseases sufficiently elaborated? Literature analysis reveals a dearth of publications on the effectiveness of both individual rehabilitation methods and complex approaches, as well as the almost complete absence of guidelines for load tolerance control. ICF is rarely used; there is no information about activity constraints and patient involvement; the impact of the environment, including parents and family, is not analyzed. There are no publications on the effectiveness of early rehabilitation in the intensive care setting. Obviously, medical rehabilitation of children with infectious diseases is still based on outdated biomedical approaches. The long overdue transition to the new model is mentioned in by a handful of authors, who provide rationale for personalized, problem-oriented and multidisciplinary approaches.

Special attention should be paid to the arguments advocating a personalized approach to the rehabilitation of children with infectious diseases that involves assessment of structural and functional damage using ICF categories [64]. The authors of the cited study conducted health assessment of 103 children discharged from the departments of respiratory, intestinal, neurological infections and hepatitis (see Table). Using ICF criteria, 5 patient groups were identified based on the severity of functional damage. Over $36 \%$ of the patients needed medical rehabilitation. The authors concluded that ICF had good potential as a tool for designing individual rehabilitation plans and controlling their implementation and effectiveness.

The cited publication was a pioneer study. It did not attempt to analyze factors limiting patient activity, patient involvement or the effects of the environment on patient progress.

The use of ICF in the therapy of children with mental conditions and hearing and speech disorders [65] and in designing rehabilitation plans for children with speech impairments [66] was discussed in earlier publications. 
Some authors highlight the economic benefits of rehabilitation [67], which can significantly improve social adaptation and daily performance of children with a past history of neuroinfection [68]. It is believed that continuity, diversity and order of rehabilitation procedures at different stages of rehabilitation is key to successful recovery. It is also important to adjust the rehabilitation plan to the patient's condition and monitor their health throughout the rehabilitation process [69].

Recently, nutritional support has been recognized as an essential rehabilitation tool complementing physical therapy and psychotherapy in the hospital setting [70].

Parents and other family members play a tremendous role in the successful rehabilitation of the child; parents should be encouraged to get more involved in order to ensure a gradual, long-lasting positive effect of rehabilitation procedures [71].

There is a pressing need for an agency that would ensure effective patient routing based on the severity of their condition. Some authors stress that rehabilitation should be started as early as possible and be patient- and problem-oriented [72-75]. Recently, telerehabilitation has been actively discussed in the literature, including its potential as a method for controlling adherence and evaluating patient performance and general health [76-78].

New software for designing rehabilitation plans is emerging. A decision support system may be helpful in deciding on the extent of interventions for pediatric rehabilitation [79]. A good example here is a guidance and a parent's diary developed by British researchers for parents whose children had a history of meningitis [80]. Development of such rehabilitation tools for basic pediatric infections is a critical milestone in the adoption of the biopsychosocial approach to patient and their family.

\section{CONCLUSION}

There is a paucity of fresh systematic reviews and original research studies on the rehabilitation of children with infectious diseases. The majority of the identified publications only describe methods of pediatric rehabilitation after infection, which raises the need for high-quality research into this problem.

Still, studies of the biomedical approach to pediatric rehabilitation will not be of much help. Earlier, an unsuccessful attempt was made to conduct a meta-analysis of studies focusing on the rehabilitation of children after infectious encephalitis [34]. Approaches to rehabilitation can be systematized by using ICF as a classification system and the basis for formulating a rehabilitation diagnosis. It will be necessary to adopt a multidisciplinary approach to the diagnostic process (to assess physical activity constraints, patient involvement and the impact of environmental factors), set the goals and objectives of interventions and elaborate the plan for their implementation.

We hope that in the nearest future medical rehabilitation of children with infectious diseases will be systematized and assimilate new methodological approaches, thereby becoming more effective, improving the quality of life of patients and their parents, and creating economic benefits for the state by maintaining health of its citizens.

\section{References}

1. Engel GL. The need for a new medical model: a challenge for biomedicine. Science. 1977 Apr 8; 196 (4286): 129-36. DOI: 10.1126/science.847460.

2. Ivanova GE, Belkin AA, Beljaev AF, Bodrova RA, Builova TV Melnikova EV, i dr. O podgotovke kadrov $v$ oblasti medicinskoj reabilitacii. Vrach po fizicheskoj i reabilitacionnoj medicine. Vestnik vosstanovitel'noj mediciny. 2017; 2 (78): 4-9. Russian.

3. Shmonin AA, Malceva MN, Melnikova EV, Ivanova GE. Bazovye principy medicinskoj reabilitacii, reabilitacionnyj diagnoz $\vee$ kategorijah MKF i reabilitacionnyj plan. Vestnik vosstanovitel'noj mediciny. 2017; 2 (78): 16-22. Russian.

4. Mezhdunarodnaja klassifikacija funkcionirovanija, ogranichenij zhiznedejatel'nosti i zdorov'ja: 54-j sessija assamblei Vsemirnoj Organizacii Zdravoohranenija 22 maja 2001 goda. Bibliotechnaja sluzhba VOZ. Sankt-Peterburgskij institut usovershenstvovanija vrachej-jekspertov Ministerstva truda i social'nogo razvitija Rossijskoj Federacii; 2003. 228 s. Russian.

5. Melnikova EV, Bujlova TV, Bodrova RA, Shmonin AA, Malceva MN Ivanova GE. Ispol'zovanie mezhdunarodnoj klassifikaci funkcionirovanija (MKF) v ambulatornoj i stacionarnoj medicinskoj reabilitacii: instrukcija dlja specialistov. Vestnik vosstanovitel'no mediciny. 2017; 6 (82): 7-20. Russian.

6. Karas AYu, Kolokolov OV, Lobacheva AV. Reabilitacija detej, perenesshih ostrye nejroinfekcii: vozmozhnostii perspektivy. $V$ sbornike: Bjulleten' medicinskih Internet-konferencij. 2012; 2 (9): 687-717. Russian.

7. Lobzin YuV, Konovalova LN, Skripchenko NV. Sostojanie infekcionnoj zabolevaemosti u detej v Rossijskoj Federacii. Medicinskie nauki. 2017; 60 (2): 8-22. Russian.

8. O sostojanii sanitarno-jepidemiologicheskogo blagopoluchija naselenija v Rossijskoj Federacii v 2018 godu. Gosudarstvenny doklad. M.: Federal'naja sluzhba po nadzoru v sfere zashhity prav potrebitelej i blagopoluchija cheloveka; 2019. 254 s. Russian.

9. Lobzin YuV, Rychkova SV, Uskov AN, Skripchenko NV, Fedorov W. Sovremennye tendencii infekcionnoj zabolevaemosti u detej $\checkmark$ Rossijskoj Federacii. Kubanskij nauchnyj medicinskij vestnik. 2020; 27 (4): 119-33. Russian.

10. Beltikova AA, Kashuba YeA, Ljubimceva OA, Petrushina AD. Infekcii u detej: mify i real'nost'. Nauka i obrazovanie: sovremennye trendy. 2015; (X): 6-11. Russian.

11. Skripchenko NV, Egorova ES. Primenenie citoflavina v kompleksnoj terapii nejroinfekcij u detej. Zhurnal nevrologii i psihiatrii. 2011; 111 (9): 28-31. Russian.

12. Shirokova AS, Skripchenko NV, Zaharycheva TA, Protasenja II. Osobennosti perioda rekonvalescencii u podrostkov, perenesshih jenterovirusnyj meningit. Nejrohirurgija i nevrologija detskogo vozrasta. 2015; 3 (45): 19-24. Russian.

13. Pronina EV, Skripchenko NV, Ivanova MV, Gonchar NV, Behtereva MK, Babachenko IV, i dr. K voprosu ob organizacii otdelenij reabilitacil v stacionarah infekcionnogo profilia dlja detej — rekonvalescentov infekcionnyh zabolevanij. Detskie infekcii. 2014; (4): 50-55. Russian.

14. Brouwer MC, McIntyre P, Prasad K, van de Beek D. Corticosteroids for acute bacterial meningitis. Cochrane Database of Systematic Reviews. 2015; (9): CD004405. DOI: 10.1002/14651858. CD004405.pub5.

15. Dorsett M, Liang S. Diagnosis and treatment of central nervous system infections in the emergency department. Emerg Med Clin North Am. 2016; 34 (4): 917-42.

16. Martin NG, Sadarangani M, Pollard AJ, Goldacre MJ. Hospital admission rates for meningitis and septicaemia caused by Haemophilus influenzae, Neisseria meningitidis, and Streptococcus pneumoniae in children in England over five decades: a populationbased observational study. Lancet Infect Dis. 2014; (14): 397-405.

17. Sadarangani M, Scheifele DW, Halperin SA. Outcomes of invasive meningococcal disease in adults and children in Canada between 2002 and 2011: a prospective cohort study. Clin Infect Dis. 2015; 60 (8): 27-35. DOI: 10.1093/cid/civ0287.

18. Wang $\mathrm{C}, \mathrm{Xu} \mathrm{H}$, Deng J, Yu H, Chen Y, Wang S et al. Prognostic 
factors in pediatric pneumococcal meningitis patients in mainland China: a retrospective multicenter study. Infect Drug Resist. 2019; (12): 1501-12. DOI: 10.2147/IDR.S193671.

19. Zalmanovici Trestioreanu A, Fraser A, Gafter-Gvili A, Paul M, Leibovici L. Antibiotics for preventing meningococcal infections, Cochrane Database Syst Rev. 2013; (10): CD004785. DOl: 10.1002/14651858.CD004785.pub5.

20. Wall EC, Ajdukiewicz KM, Bergman H, Heyderman RS, Garner P. Osmotic therapies added to antibiotics for acute bacterial meningitis. Cochrane Database Syst Rev. 2018; (2): CD008806. DOI: 10.1002/14651858.CD008806. pub3

21. Maconochie IK, Bhaumik S. Fluid therapy for acute bacterial meningitis. Cochrane Database Syst Rev. 2016; (11): CD004786.

22. Iro MA, Sadarangani M, Goldacre R. 30-year trends in admission rates for encephalitis in children in England and effect of improved diagnostics and measles-mumps-rubella vaccination: a population-based observational study. Lancet Infect Dis. 2017; 17 (4): 422-30. DOI: 10.1016/S1473-3099(17)30114-7.

23. Skripchenko NV, Ivanova MV, Vilnic AA, Skripchenko EYu. Nejroinfekcii u detej: tendencii i perspektivy. Rossijskij vestnik perinatologii i pediatrii. 2016; (4): 9-22. Russian.

24. Samojlova IG. Jekonomicheskaja jeffektivnost' reabilitacii dete posle nejroinfekcij. Vjatskij medicinskij vestnik. 2019; (1): 64-6. Russian.

25. Pillai SC, Mohammad SS, Hacohen Y, Tantsis E, Prelog K, Barnes EH et al. Postencephalitic epilepsy and drug-resistant epilepsy after infectious and antibody-associated encephalitis in childhood: Clinical and etiologic risk factors. Epilepsia. 2016; 57 (1): 7-11. DOI: 10.1111/epi.13253.

26. Ellul M, Solomon T. Acute encephalitis - diagnosis and management. Clinical Med London. 2018; 18 (2): 155-9. DOl: 10.7861/clinmedicine.18-2-155

27. Fowler A, Forsman L, Eriksson M, Wickstöm R. Tick-borne encephalitis carries a high risk of incomplete recovery in children. J Pediatr. 2013; 163 (2): 555-60. DOI: 10.1016/j. jpeds.2013.01.037.

28. Karlov VA, Morozova EA, Ratner FL, Morozov DV, Petrova AV, Bagirova SF, i dr. Osobennosti techenija jepilepsii i kognitivnye rasstrojstva u detej s perinatal'noj patologiej mozga. Psihicheskoe zdorov'e. 2017; 15 (1): 29-37. Russian.

29. Michaeli O, Kassis I, Shachor-Meyouhas Y. Long-term motor and cognitive outcome of acute encephalitis. Pediatrics. 2014; 133 (3): e546-52. DOI: 10.1542/peds.2013-3010.

30. Huang L, Yu D, Luo R, Li M, Zhou H, Cai XT et al. Risk factors and prognosis of secondary epilepsy in children with viral encephalitis. Sichuan Da Xue Xue Bao Yi Xue Ban. 2017; 48 (2): 257-62.

31. Pandey S, Rathore C, Michael BD. Antiepileptic drugs for the primary and secondary prevention of seizures in viral encephalitis. Cochrane Database Syst Rev. 2016; 22 (5). DOI: 0.1002/14651858. CD010247.pub2.

32. Roed C, Sørensen HT, Rothman KJ. Employment and disability pension after central nervous system infections in adults. Am J Epidemiol. 2015; 181 (10): 789-98. DOI: 10.1093/aje/kwu359.

33. Christie S, Chan V, Mollayeva T, Colantonio A. Rehabilitation interventions in children and adults with infectious encephalitis: a systematic review protocol. BMJ Open. 2016; 6 (3): e010754 DOI: 10.1136/bmjopen-2015-010754.

34. Christie S, Chan V, Mollayeva T, Colantonio A. Systematic review of rehabilitation intervention outcomes of adult and pediatric patients with infectious encephalitis. BMJ. 2018; 8 (5): e015928. DOI: 10.1136/bmjopen-2017-015928.

35. Ramanuj PP, Granerød J, Davies NWS. Quality of life and associated socio-clinical factors after encephalitis in children and adults in England: a population-based, prospective cohor study. PLoS One. 2014; 9 (7): e103496. DOI: 10.1371/journal. pone.0103496

36. Morozova EA, Ertahova ML. Ishody nejroinfekcij i ih prediktory. Russkij zhurnal detskoj nevrologii. 2020; 15 (3-4): 55-64. Russian.

37. O sostojanii sanitarno-jepidemiologicheskogo blagopoluchija naselenija v Rossijskoj Federacii v 2020 godu. Gosudarstvenny] doklad. M.: Federal'naja sluzhba po nadzoru v sfere zashhity prav potrebitelej i blagopoluchija cheloveka; 2021. 256 s. Russian.

38. Mazankova LN, Gorbunov SG. Infekcionnye bolezni u detej: aktual'nost' i mezhdisciplinarnye aspekty podgotovki pediatrov v sisteme poslediplomnogo obrazovanija vrachej. Rossijskij vestnik perinatologii i pediatrii. 2012; 57 (1): 4-7. Russian.

39. Gorelov AV, Grigorovich MS. Ostrye kishechnye infekcii u detej: otdalennye ishody, faktory, ih opredeljajushhie. Optimizacija putej reabilitacii. Moskva - Kirov, 2012; 206 s. Russian.

40. Medicinskaja reabilitacija detej, perenesshih novuju koronavirusnuju infekciju (Covid-19) v medicinskih organizacijah, podvedomstvennyh FMBA Rossii. Metodicheskie rekomendacii. Sankt-Peterburg, 2020; 40 s. Russian.

41. Galimzjanova ASh, Sharafeeva EE, Komina AN. Osnovnye principy fizioterapii. Pediatricheskij vestnik juzhnogo Urala. 2013; (2): 58-61. Russian.

42. Gorbacheva KV. Vozmozhnost' korrekcii disbioza kishechnika pri primenenii metodov fizioterapii. Gastrojenterologija SanktPeterburga. 2011; (2-3): M19-M20. Russian.

43. Han MA, Talkovskij EM. Vosstanovitel'noe lechenie detej s vospalitel'nymi zabolevanijami tolstoj kishki. Vestnik vosstanovitel'noj mediciny. 2012; 4 (50): 46-50. Russian.

44. Lagunova NV, Marchukova AYu, Lebedeva TN. Primenenie chastotno-rezonansnoj terapii $v$ sanatorno-kurortnoj reabilitacii detej s sindromom razdrazhennogo kishechnika. Nauchnye vedomosti belgorodskogo gosudarstvennogo universiteta. Serija: medicina. Farmacija. 2017; 5 (254): 52-58. Russian.

45. Babachenko IV, Levina AS, Chuprova SN, Sharipova EV. Porazhenija serdca pri respiratornyh infekcijah u detej. Zhurnal Infektologii. 2016; 8 (4): 20-25. Russian.

46. Nacional'nye rekomendacii po dopusku sportsmenov s otklonenijami so storony serdechno-sosudistoj sistemy $k$ trenirovochno-sorevnovatel'nomu processu. Racional'naja Farmakoterapija v Kardiologii. 2011; Prilozhenie \# 6: 2-60. Russian.

47. Nikitina IL, Vershinina TL. Miokardit u detej: problemy i reshenija. Medicinskii sovet. 2017; (1): 238-45. Russian.

48. Zimmermann $P$, Curtis N. Coronavirus infections in children including COVID-19, an overview of the epidemiology, clinical features, diagnosis, treatment and prevention options in children. The Pediatric Infectious Disease Journal. 2020; 39 (5): 355-68.

49. Su L, Ma X, Yu H, Zhang Z, Bian P, Han Y, et al. The different clinical characteristics of corona virus disease cases between children and their families in China - the character of children with COVID-19. Emerging Microbes \& Infections. 2020; 9 (1): 707-13. DOI: 10.1080/22221751. 2020.1744483.

50. Lobzin YuV, Cherkashina IV, Samojlova IG. Medicinskaja reabilitacija detej, perenesshih COVID-19. Zhurnal infektologii. 2020; 12 (3): 64-74. Russian.

51. Cruz AT, Zeichner SL. COVID-19 in Children: Initial Characterization of the Pediatric Disease. Pediatrics. 2020; 145 (6): e20200834.

52. Xia W, Shao J, Guo Y, Peng X, Li Z, Hu D. Clinical and CT features in pediatric patients with COVID19 infection: Different points from adults. Pediatric Pulmonology. 2020; 55: 1169-74. DOI: 10.1002/ ppul.24718

53. Zvereva NN, Sajfullin MA, Rtishhev AYu, Shamsheva OV, Pshenichnaja NYu. Koronavirusnaja infekcija u detej. Zhurnal pediatrii im. G. N. Speranskogo. 2020; 99 (2): 270-8. Russian.

54. Wang S, Guo L, Chen L, Liu W, Cao Y, Zhang J, et al. A case report of neonatal COVID-19 infection in China. Infectious Diseases Society of America. 2020; DOI: 10.1093/cid/ciaa225.

55. Xia W, Shao J, Guo Y, Peng X, Li Z, Hu D. Clinical and CT features in pediatric patients with COVID19 infection: Different points from adults. Pediatric Pulmonology. 2020; 55: 1169-74. DOI: 10.1002/ ppul.24718.

56. Qiu $H$, Wu J, Hong L, Luo $Y$, Song $Q$, Chen D. Clinical and epidemiological features of 36 children with coronavirus disease 2019 (COVID-19) in Zhejiang. China: an observational cohort study. The Lancet Infectious Diseases. 2020; 20 (6): 689-96. DOI: 10.1016/S1473-3099(20)30198-5.

57. Belopasov W, Jashu Ya, Samojlova EM, Baklaushev VP. Porazhenie nervnoj sistemy pri Sovid-19. Klinicheskaja praktika. 2020; 11 (2): 60-80. Russian.

58. Jin X, Lian J-S, Hu J-H, Gao J, Zheng L, Zhang Y-M, et al. Epidemiological, clinical and virological characteristics of 74 cases of coronavirus-infected disease 2019 (COVID-19) with 
gastrointestinal symptoms. Gut. 2020: 69 (6): 1002-9. DOI: 10.1136/gutjnl-2020-320926.

59. Gu J, Han B, Wang J. COVID-19: Gastrointestinal manifestations and potential fecal-oral transmission. Gastroenterology. 2020; 158 (6): 1518-9. DOI: 10.1053/j.gastro.2020.02.054.

60. Panda PK, Sharawat IK. COVID-19 (SARS-CoV-2 Infection) and children: pediatric neurologist's perspective. The Indian Journal of Pediatrics. 2020; 87 (7): 556-7. DOI: 10.1007/s12098-020-03326-8.

61. Kopishinskaya SV, Zharinova NO, Velichko IA, Zhukova NG, Bucev VV, Korobejnikov IV, i dr. Osnovnye principy vedenija nevrologicheskih pacientov v period pandemii COVID-19. Nervnomyshechnye bolezni. 2020; 10 (1): 31-42. DOI: 10.17650/22228721-2020-10-1-31-42. Russian.

62. Petrova MS, Han MA. Medicinskaja reabilitacija detej, perenesshih novuju koronavirusnuju infekciju COVID-19. Vestnik vosstanovitel'noj mediciny. 2021; 20 (4): 4-12. Russian.

63. Vremennye metodicheskie rekomendacii Minzdrava Rossi «Medicinskaja reabilitacija pri novoj koronavirusnoj infekci (COVID-19) versija 2 (31.07.2020). Russian.

64. Skripchenko NV, Pronina EV, Lepihina TG, Vladimirova ON, Ivanova MV, Gonchar NV, i dr. Medicinskaja reabilitacija detejrekonvalescentov infekcionnyh zabolevanij $v$ svete predstavleni] mezhdunarodnoj klassifikacii funkcionirovanija, ogranichenij zhiznedejatel'nosti i zdorov'ja. Pediatrija. 2015; VI (3): 41-47. Russian.

65. Karaush IS, Kupriyanova IE. Vozmozhnosti primenenija Mezhdunarodnoj klassifikacii funkcionirovanija $v$ izucheni psihicheskogo zdorov'ja detej s sensornymi narushenijami. Social'naja i klinicheskaja psihiatrija. 2014; 24 (4): 62-68. Russian.

66. Westby C. Application of the ICF in children with language impairments. Seminars in speech and language. 2007; 28 (4): 265-72.

67. Batysheva TT, Lilin ET, Kvasova OV, Glazkova SV. Sravnitel'nye problemy reabilitacii. Detskaja i podrostkovaja reabilitacija. 2015; 1 (24): 11-14. Russian.

68. Samojlova IG. Jekonomicheskaja jeffektivnost' reabilitacii detej posle nejroinfekcij. Vjatskij medicinskij vestnik. 2019; 1 (61): 64 66. Russian.

\section{Литература}

1. Engel GL. The need for a new medical model: a challenge for biomedicine. Science. 1977 Apr 8; 196 (4286): 129-36. DOI: 10.1126/science.847460.

2. Иванова Г. Е., Белкин А. А., Беляев А. Ф., Бодрова Р. А., Буйлова Т. В., Мельникова Е. В. и др. О подготовке кадров в области медицинской реабилитации. Врач по физической и реабилитационной медицине. Вестник восстановительной медицины. 2017; 2 (78): 4-9.

3. Шмонин А. А., Мальцева М. Н., Мельникова Е. В., Иванова Г. Е. Базовые принципы медицинской реабилитации, реабилитационный диагноз В категориях МКФ реабилитационный план. Вестник восстановительной медицины. 2017; 2 (78): 16-22.

4. Международная классисикация функционирования, ограничений жизнедеятельности и здоровья: 54-й сессия ассамблеи Всемирной Организации Здравоохранения 22 мая 2001 года. Библиотечная служба ВОЗ. СанктПетербургский институт усовершенствования врачейэкспертов Министерства труда и социального развития Российской Федерации; 2003. 228 с.

5. Мельникова Е. В., Буйлова Т. В., Бодрова Р. А., Шмонин А. А., Мальцева М. Н., Иванова Г. Е. Использование международной классификации функционирования (МКФ) в амбулаторной и стационарной медицинской реабилитации: инструкция для специалистов. Вестник восстановительной медицины. 2017; 6 (82): 7-20.

6. Карась А. Ю., Колоколов О. В., Лобачева А. В. Реабилитация детей, перенесших острые нейроинфекции: возможностии перспективы. В сборнике: Бюллетень медицинских Интернетконференций. 2012; 2 (9): 687-717.
69. Lobzin YuV, Zaharov VI. Medicinskaja reabilitacija infekcionnyh bol'nyh i dinamicheskij kontrol' za perebolevshimi. SPb.: Izd-vo SZGMU im. I. I. Sechenova, 2015; 184 s. Russian.

70. Lajsheva OA. Vosstanovitel'noe lechenie v pediatrii. Fizkul'tura sport. 2016; 1 (133): 29-35. Russian.

71. Han MA, Tulenkova TE. Abilitacija detej grupp perinatal'nogo riska $\checkmark$ centre zdorov'ja. Vestnik vosstanovitel'noj mediciny. 2014; 4 (62): 57-63.

72. Samojlova IG Perspektivy razvitija medicinskoj i social'noj reabilitacii detej, perenesshih nejroinfekcii. Vestnik Vserossijskogo obshhestva specialistov po mediko-social'noj jekspertize, reabilitacii i reabilitacionnoj industrii. 2017; (1): 42-46. Russian.

73. Samojlova IG. Dostupnost' i kachestvo organizacii medicinskoj reabilitacii detej posle nejroinfekcij. Mediko-social'naja jekspertiza i reabilitacija. 2018; 21 (3-4): 126-8. DOI: 10.18821/1560-95372018-21-3-126-12. Russian.

74. Batysheva TT, Krapivkin Al, Caregorodcev AD, Suhorukov VS, Tihonov SV. Reabilitacija detej s porazheniem central'noj nervnoj sistemy. Rossijskij vestnik perinatologii i pediatrii. 2017; 62 (6): 7-15. DOI: 10.21508/1027-4065-2017-62-6-7-15. Russian.

75. Mamatova DM. Medicinskaja reabilitacija v period vyzdorovlenija posle infekcionnyh zabolevanij. Vestnik nauki. 2021; 2-4 (37): 81-84. Russian.

76. Adams R, Jones A, Lefmann S, Sheppard L. Rationing is a reality in rural physiotherapy: a qualitative exploration of service level decision-making. BMC Health Serv Res. 2015; 15: 121.

77. Samojlova IG. Proshloe, nastojashhee i budushhee v reabilitacil detej, perenesshih nejroinfekcii. Detskaja i podrostkovaja reabilitacija. 2018; 2 (34): 19-26. Russian

78. Demchenko EA, Krasnikova WV, Yanishevskij SN. Prakticheskie rekomendacii po fizicheskoj reabilitacii bol'nyh s tjazhelym techeniem COVID-19 v otdelenijah reanimacii i intensivnoj terapii. Arterial'naja gipertenzija. 2020; 26 (3): 327-42. Russian.

79. Jebiem ChD, Zhukova MA. Ispol'zovanie sistem podderzhk prinjatij vrachebnyh reshenij $\vee$ nevrologii. E-Scio. 2021; 6 (57): 247-56. Russian.

80. Available from: https://www.physio.co.uk/what-we-treat/ paediatric/conditions/toddlers/ meningitis.php.

7. Лобзин Ю. В., Коновалова Л. Н., Скрипченко Н. В. Состояние инфекционной заболеваемости у детей в Российской Федерации. Медицинские науки. 2017; 60 (2): 8-22.

8. О состоянии санитарно-эпидемиологического благополучия населения в Российской Федерации в 2018 году. Государственный доклад. М.: Федеральная служба по надзору в сфере защиты прав потребителей и благополучия человека; 2019. 254 с.

9. Лобзин Ю. В., Рычкова С. В., Усков А. Н., Скрипченко Н. В., Федоров В. В. Современные тенденции инфекционной заболеваемости у детей в Российской Федерации. Кубанский научный медицинский вестник. 2020; 27 (4): 119-133.

10. Бельтикова А. А., Кашуба Э. А., Любимцева О. А., Петрушина А. Д. Инфекции у детей: мифы и реальность. Наука и образование: современные тренды. 2015; (X): 6-11.

11. Скрипченко Н. В., Егорова Е. С. Применение цитославина в комплексной терапии нейроинфекций у детей. Журнал неврологии и психиатрии. 2011; 111 (9): 28-31.

12. Широкова А. С., Скрипченко Н. В., Захарычева Т. А., Протасеня И. И. Особенности периода реконвалесценции у подростков, перенесших энтеровирусный менингит. Нейрохирургия и неврология детского возраста. 2015; 3 (45): $19-24$.

13. Пронина Е. В., Скрипченко Н. В., Иванова М. В., Гончар Н. В., Бехтерева М. К., Бабаченко И. В. и др. К вопросу об организации отделений реабилитации в стационарах инфекционного просиля для детей - реконвалесцентов инфекционных заболеваний. Детские инфекции. 2014; (4): 50-55.

14. Brouwer MC, Mclntyre P, Prasad K, van de Beek D. Corticosteroids 
for acute bacterial meningitis. Cochrane Database of Systematic Reviews. 2015; (9): CD004405. DOI: 10.1002/14651858. CD004405.pub5

15. Dorsett M, Liang S. Diagnosis and treatment of central nervous system infections in the emergency department. Emerg Med Clin North Am. 2016; 34 (4): 917-42.

16. Martin NG, Sadarangani M, Pollard AJ, Goldacre MJ. Hospital admission rates for meningitis and septicaemia caused by Haemophilus influenzae, Neisseria meningitidis, and Streptococcus pneumoniae in children in England over five decades: a populationbased observational study. Lancet Infect Dis. 2014; (14): 397-405.

17. Sadarangani M, Scheifele DW, Halperin SA. Outcomes of invasive meningococcal disease in adults and children in Canada between 2002 and 2011: a prospective cohort study. Clin Infect Dis. 2015; 60 (8): 27-35. DOI: 10.1093/cid/civ0287.

18. Wang C, Xu H, Deng J, Yu H, Chen Y, Wang S et al. Prognostic factors in pediatric pneumococcal meningitis patients in mainland China: a retrospective multicenter study. Infect Drug Resist. 2019; (12): 1501-12. DOI: 10.2147/IDR.S193671.

19. Zalmanovici Trestioreanu A, Fraser A, Gafter-Gvili A, Paul M, Leibovici L. Antibiotics for preventing meningococcal infections. Cochrane Database Syst Rev. 2013; (10): CD004785. DOI: 10.1002/14651858.CD004785.pub5

20. Wall EC, Ajdukiewicz KM, Bergman H, Heyderman RS, Garner P. Osmotic therapies added to antibiotics for acute bacterial meningitis. Cochrane Database Syst Rev. 2018; (2): CD008806. DOI: 10.1002/14651858.CD008806. pub3.

21. Maconochie IK, Bhaumik S. Fluid therapy for acute bacterial meningitis. Cochrane Database Syst Rev. 2016; (11): CD004786.

22. Iro MA, Sadarangani M, Goldacre R. 30-year trends in admission rates for encephalitis in children in England and effect of improved diagnostics and measles-mumps-rubella vaccination: a population-based observational study. Lancet Infect Dis. 2017; 17 (4): 422-30. DOI: 10.1016/S1473-3099(17)30114-7.

23. Скрипченко Н. В., Иванова М. В., Вильниц А. А., Скрипченко Е. Ю. Нейроинфекции у детей: тенденции и перспективы. Российский вестник перинатологии и педиатрии. 2016; (4): 9-22.

24. Самойлова И. Г. Экономическая эфффективность реабилитации детей после нейроинфекций. Вятский медицинский вестник. 2019; (1): 64-6.

25. Pillai SC, Mohammad SS, Hacohen Y, Tantsis E, Prelog K, Barnes EH et al. Postencephalitic epilepsy and drug-resistant epilepsy after infectious and antibody-associated encephalitis in childhood: Clinical and etiologic risk factors. Epilepsia. 2016; 57 (1): 7-11. DOI: 10.1111/epi.13253.

26. Ellul M, Solomon T. Acute encephalitis - diagnosis and management. Clinical Med London. 2018; 18 (2): 155-9. DOI 10.7861/clinmedicine.18-2-155.

27. Fowler A, Forsman L, Eriksson M, Wickstöm R. Tick-borne encephalitis carries a high risk of incomplete recovery in children. J Pediatr. 2013; 163 (2): 555-60. DOI: 10.1016/j. jpeds.2013.01.037.

28. Карлов В. А., Морозова Е. А., Ратнер Ф. Л., Морозов Д. В., Петрова А. В., Багирова С. Ф. и др. Особенности течения эпилепсии и когнитивные расстройства у детей с перинатальной патологией мозга. Психическое здоровье. 2017; 15 (1): 29-37.

29. Michaeli O, Kassis I, Shachor-Meyouhas Y. Long-term motor and cognitive outcome of acute encephalitis. Pediatrics. 2014; 133 (3): e546-52. DOI: 10.1542/peds.2013-3010.

30. Huang L, Yu D, Luo R, Li M, Zhou H, Cai XT et al. Risk factors and prognosis of secondary epilepsy in children with viral encephalitis. Sichuan Da Xue Xue Bao Yi Xue Ban. 2017; 48 (2): 257-62.

31. Pandey S, Rathore C, Michael BD. Antiepileptic drugs for the primary and secondary prevention of seizures in viral encephalitis. Cochrane Database Syst Rev. 2016; 22 (5). DOI: 0.1002/14651858. CD010247.pub2.

32. Roed C, Sørensen HT, Rothman KJ. Employment and disability pension after central nervous system infections in adults. Am Epidemiol. 2015; 181 (10): 789-98. DOI: 10.1093/aje/kwu359.

33. Christie S, Chan V, Mollayeva T, Colantonio A. Rehabilitation interventions in children and adults with infectious encephalitis: a systematic review protocol. BMJ Open. 2016; 6 (3): e010754. DOI: 10.1136/bmjopen-2015-010754.

34. Christie S, Chan V, Mollayeva T, Colantonio A. Systematic review of rehabilitation intervention outcomes of adult and pediatric patients with infectious encephalitis. BMJ. 2018; 8 (5): e015928. DOI: 10.1136/bmjopen-2017-015928.

35. Ramanuj PP, Granerød J, Davies NWS. Quality of life and associated socio-clinical factors after encephalitis in children and adults in England: a population-based, prospective cohort study. PLoS One. 2014; 9 (7): e103496. DOI: 10.1371/journal. pone.0103496

36. Морозова Е. А., Ертахова М. Л. Исходы нейроинсекций и их предикторы. Русский журнал детской неврологии. 2020; 15 (3-4): 55-64.

37. О состоянии санитарно-эпидемиологического благополучия населения В Российской Федерации в 2020 году. Государственный доклад. М.: Федеральная служба по надзору в сфере защиты прав потребителей и благополучия человека; 2021. 256 с.

38. Мазанкова Л. Н., Горбунов С. Г. Инфекционные болезни у детей: актуальность и междисциплинарные аспекты подготовки педиатров в системе последипломного образования врачей. Российский вестник перинатологии и педиатрии. 2012; 57 (1): 4-7.

39. Горелов А. В., Григорович М. С. Острые кишечные инфекции у детей: отдаленные исходы, факторы, их определяющие. Оптимизация путей реабилитации. Москва - Киров, 2012; 206 c.

40. Медицинская реабилитация детей, перенесших новую коронавирусную инфекцию (Covid-19) в медицинских организациях, подведомственных ФМБА России. Методические рекомендации. Санкт-Петербург, 2020; 40 с.

41. Галимзянова А. Ш., Шарафеева Е. Е., Комина А. Н. Основные принципы физиотерапии. Педиатрический вестник южного Урала. 2013; (2): 58-61.

42. Горбачева К. В. Возможность коррекции дисбиоза кишечника при применении методов физиотерапии. Гастроэнтерология Санкт-Петербурга. 2011; (2-3): М19-М20.

43. Хан М. А., Тальковский Е. М. Восстановительное лечение детей с воспалительными заболеваниями толстой кишки. Вестник восстановительной медицины. 2012; 4 (50): 46-50.

44. Лагунова Н. В., Марчукова А. Ю., Лебедева Т. Н. Применение частотно-резонансной терапии в санаторно-курортной реабилитации детей с синдромом раздраженного кишечника. Научные ведомости белгородского государственного университета. Серия: медицина. Фармация. 2017; 5 (254): 52-58.

45. Бабаченко И. В., Левина А. С., Чупрова С. Н., Шарипова Е. В. Поражения сердца при респираторных инфекциях у детей. Журнал Инфектологии. 2016; 8 (4): 20-25.

46. Национальные рекомендации по допуску спортсменов с отклонениями со стороны сердечно-сосудистой системы к тренировочно-соревновательному процессу. Рациональная Фармакотерапия в Кардиологии. 2011; Приложение № 6: 2-60.

47. Никитина И. Л., Вершинина Т. Л. Миокардит у детей: проблемы и решения. Медицинский совет. 2017; (1): 238-45.

48. Zimmermann $\mathrm{P}$, Curtis N. Coronavirus infections in children including COVID-19, an overview of the epidemiology, clinical features, diagnosis, treatment and prevention options in children. The Pediatric Infectious Disease Journal. 2020; 39 (5): 355-68.

49. Su L, Ma X, Yu H, Zhang Z, Bian P, Han Y, et al. The different clinical characteristics of corona virus disease cases between children and their families in China - the character of children with COVID-19. Emerging Microbes \& Infections. 2020; 9 (1): 707-13. DOI: 10.1080/22221751. 2020.1744483.

50. Лобзин Ю. В., Черкашина И. В., Самойлова И. Г. Медицинская реабилитация детей, перенесших COVID-19. Журнал инсектологии. 2020; 12 (3): 64-74.

51. Cruz AT, Zeichner SL. COVID-19 in Children: Initial Characterization of the Pediatric Disease. Pediatrics. 2020; 145 (6): e20200834.

52. Xia W, Shao J, Guo Y, Peng X, Li Z, Hu D. Clinical and CT features 
in pediatric patients with COVID19 infection: Different points from adults. Pediatric Pulmonology. 2020; 55: 1169-74. DOI: 10.1002/ ppul.24718.

53. Зверева Н. Н., Сайфуллин М. А., Ртищев А. Ю., Шамшева О. В., Пшеничная Н. Ю. Коронавирусная инфекция у детей. Журнал педиатрии им. Г. Н. Сперанского. 2020; 99 (2): 270-8.

54. Wang S, Guo L, Chen L, Liu W, Cao Y, Zhang J, et al. A case report of neonatal COVID-19 infection in China. Infectious Diseases Society of America. 2020; DOI: 10.1093/cid/ciaa225.

55. Xia W, Shao J, Guo Y, Peng X, Li Z, Hu D. Clinical and CT features in pediatric patients with COVID19 infection: Different points from adults. Pediatric Pulmonology. 2020; 55: 1169-74. DOI: 10.1002/ ppul.24718.

56. Quu H, Wu J, Hong L, Luo Y, Song Q, Chen D. Clinical and epidemiological features of 36 children with coronavirus disease 2019 (COVID-19) in Zhejiang, China: an observational cohort study. The Lancet Infectious Diseases. 2020; 20 (6): 689-96. DOI: 10.1016/S1473-3099(20)30198-5.

57. Белопасов В. В., Яшу Я., Самойлова Е. М., Баклаушев В. П. Поражение нервной системы при Covid-19. Клиническая практика. 2020; 11 (2): 60-80.

58. Jin X, Lian J-S, Hu J-H, Gao J, Zheng L, Zhang Y-M, et al. Epidemiological, clinical and virological characteristics of 74 cases of coronavirus-infected disease 2019 (COVID-19) with gastrointestinal symptoms. Gut. 2020: 69 (6): 1002-9. DOI: 10.1136/gutjnl-2020-320926.

59. Gu J, Han B, Wang J. COVID-19: Gastrointestinal manifestations and potential fecal-oral transmission. Gastroenterology. 2020; 158 (6): 1518-9. DOI: 10.1053/j.gastro.2020.02.054.

60. Panda PK, Sharawat IK. COVID-19 (SARS-CoV-2 Infection) and children: pediatric neurologist's perspective. The Indian Journal of Pediatrics. 2020; 87 (7): 556-7. DOI: 10.1007/s12098-02003326-8.

61. Копишинская С. В., Жаринова Н. О., Величко И. А., Жукова Н. Г., Буцев В. В., Коробейников И. В. и др. Основные принципы ведения неврологических пациентов в период пандемии COVID-19. Нервно-мышечные болезни. 2020; 10 (1): 31-42. DOI: 10.17650/2222-8721-2020-10-1-31-42

62. Петрова М. С., Хан М. А. Медицинская реабилитация детей, перенесших новую коронавирусную инфекцию COVID-19. Вестник восстановительной медицины. 2021; 20 (4): 4-12.

63. Временные методические рекомендации Минздрава России «Медицинская реабилитация при новой коронавирусной инфекции (COVID-19) версия 2 (31.07.2020).

64. Скрипченко Н. В., Пронина Е. В., Лепихина Т. Г., Владимирова О. Н., Иванова М. В., Гончар Н. В. и др. Медицинская реабилитация детей-реконвалесцентов инфекционных заболеваний в свете представлений международной классификации функционирования, ограничений жизнедеятельности и здоровья. Педиатрия. 2015; VI (3): 41-47.

65. Карауш И. С., Куприянова И. Е. Возможности применения Международной классификации функционирования В изучении психического здоровья детей с сенсорными нарушениями. Социальная и клиническая психиатрия. 2014; 24 (4): 62-68

66. Westby C. Application of the ICF in children with language impairments. Seminars in speech and language. 2007; 28 (4): $265-72$.

67. Батышева Т. Т., Лильин Е. Т., Квасова О. В., Глазкова С. В. Сравнительные проблемы реабилитации. Детская и подростковая реабилитация. 2015; 1 (24): 11-14.

68. Самойлова И. Г. Экономическая эффеективность реабилитации детей после нейроинфекций. Вятский медицинский вестник. 2019; 1 (61): 64-66.

69. Лобзин Ю. В., Захаров В. И. Медицинская реабилитация инфекционных больных и динамический контроль за переболевшими. СПб.: Изд-во СЗГМУ им. И. И. Сеченова, 2015; 184 c.

70. Лайшева О. А. Восстановительное лечение в педиатрии. Физкультура и спорт. 2016; 1 (133): 29-35.

71. Хан М. А., Туленкова Т. Е. Абилитация детей групп перинатального риска в центре здоровья. Вестник восстановительной медицины. 2014; 4 (62): 57-63.

72. Самойлова И.Г Перспективы развития медицинской и социальной реабилитации детей, перенесших нейроинфекции. Вестник Всероссийского общества специалистов по медикосоциальной экспертизе, реабилитации и реабилитационной индустрии. 2017; (1): 42-46.

73. Самойлова И. Г. Доступность и качество организации медицинской реабилитации детей после нейроинфекций. Медико-социальная экспертиза и реабилитация. 2018; 21 (3-4): 126-8. DOI: 10.18821/1560-9537-2018-21-3-126-12.

74. Батышева Т. Т., Крапивкин А. И., Царегородцев А. Д., Сухоруков В. С., Тихонов С. В. Реабилитация детей с поражением центральной нервной системы. Российский вестник перинатологии и педиатрии. 2017; 62 (6): 7-15. DOI: 10.21508/1027-4065-2017-62-6-7-15.

75. Маматова Д. М. Медицинская реабилитация в период выздоровления после инсекционных заболеваний. Вестник науки. 2021; 2-4 (37): 81-84.

76. Adams R, Jones A, Lefmann S, Sheppard L. Rationing is a reality in rural physiotherapy: a qualitative exploration of service level decision-making. BMC Health Serv Res. 2015; 15: 121.

77. Самойлова И. Г. Прошлое, настоящее и будущее в реабилитации детей, перенесших нейроинфекции. Детская и подростковая реабилитация. 2018; 2 (34): 19-26.

78. Демченко Е. А., Красникова В. В., Янишевский С. Н. Практические рекомендации по физической реабилитации больных с тяжелым течением COVID-19 в отделениях реанимации и интенсивной терапии. Артериальная гипертензия. 2020; 26 (3): 327-42.

79. Эбием Ч. Д., Жукова М. А. Использование систем поддержки принятий врачебных решений в неврологии. E-Scio. 2021; 6 (57): 247-56.

80. Available from: https://www.physio.co.uk/what-we-treat/ paediatric/conditions/toddlers/ meningitis.php. 